DOI: $10.4312 / \mathrm{mz} .55 .2 .19-21$

\title{
Ursula Hemetek
}

Inštitut za raziskovanje ljudske glasbe in etnomuzikologijo,

Univerza za glasbo in uprizoritveno umetnost, Dunaj

Mednarodni svet za tradicijsko glasbo

The Department of Folk Music Research and Ethnomusicology,

University for Music and the Performing Arts, Vienna

International Council for Traditional Music

\section{Identities of Svanibor Pettan}

Without doubt every individual has multiple identities. In our longstanding friendship I have witnessed some of Svanibor's: ethnically Slovenian as well as Croatian, ethnomusicologist, engaged activist, ICTM official, white male, caring son, loving husband and loyal friend. And there would be many more to mention. Here I want to concentrate on some of his outstanding characteristics in his professional career. My thoughts are based on my personal perceptions.

\section{The "modern ethnomusicologist"}

Maybe it sounds strange to use the attribute "modern" for a person within a discipline. Such attributes are always very much connected to time and place and of course as opposed to something that would not be modern. In Svanibor's case I think it does make sense, especially seen against the background of the time and the region where his career started. Svanibor himself defined what he meant by modern ethnomusicology in an article from 2001 with the title "Encounter with 'The Others from Within': The Case of Gypsy Musicians in Former Yugoslavia”. The article is about Romani music, and this genre demands approaches that are opposed to certain ones which we could call "the conservative folk music research" approach. As I do research on Romani music as well, that article for me was crucial. I have made a table using some keywords from Pettan's conclusion which corresponds to the approaches of the two disciplines personified by the objects of research. It reads as follows and underlines the differences and paradoxes: 


\begin{tabular}{|l|l|}
\hline $\begin{array}{l}\text { Conservative folk music researcher } \\
\text { Folklore ensemble }\end{array}$ & $\begin{array}{l}\text { Modern ethnomusicologist } \\
\text { Gypsy musicians }\end{array}$ \\
\hline $\begin{array}{l}\text { responsibility for one's own national } \\
\text { roots }\end{array}$ & open-mindedness towards the "other" \\
\hline national & global framework \\
\hline self-sufficiency & openness \\
\hline interest in the survival of products & $\begin{array}{l}\text { interest in processes: acculturation, glo- } \\
\text { balization, construction of identity }\end{array}$ \\
\hline $\begin{array}{l}\text { characteristic "we" pattern, collective } \\
\text { identities }\end{array}$ & "I" pattern, individuality \\
\hline
\end{tabular}

Pettan uses the Roma as an example to analyze and to challenge the methodologies and theories of folk music research and ethnomusicology. For me this analysis was rather enlightening at that time, and it was provocative. It was provocative for certain parts of Europe too, especially some states of Southeast Europe, but also for Austria. Pettan was clearly defining his own position as a modern ethnomusicologist in confrontation with conservative folk music researchers, the latter being a model of an academic discipline which was still dominant in some national scholarly traditions at that time. This is only one of many outstanding achievements of Svanibor's scholarly approaches.

\section{The minority researcher}

We have collaborated for about 30 years now in different projects and on different levels in the field of ethnomusicological minority research. The umbrella for most of these activities was the ICTM.

On the one hand, we co-founded the Study Group on Music and Minorities in 1999, while the preparations had already begun in 1994. It was not an easy task but we joined forces with many other colleagues and finally succeeded. In 2000, the first Study Group symposium took place in Ljubljana, and it was the point of departure for a very successful ongoing process. Both of us are still minority researchers and we are both involved in Roma research. Svanibor added another approach, probably also due to his personal history of being involved in the war in the former Yugoslavia: applied ethnomusicology. He was the co-founder of the ICTM Study group on Applied Ethnomusicology and its first chair. The founding took place during the World Conference 2007 in Vienna. His longstanding scholarly engagement culminated in the co-editing of The Oxford Handbook of Applied Ethnomusicology in 2015. 


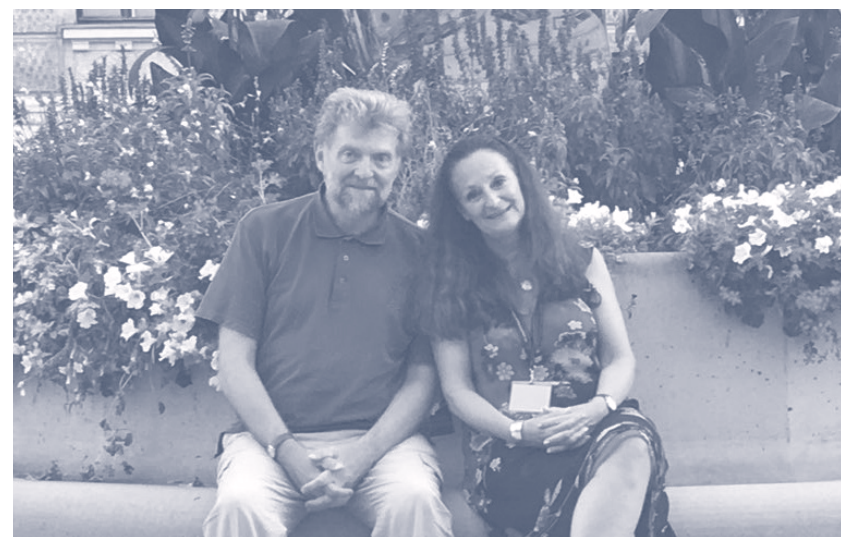

Picture 1: Ursula Hemetek and Svanibor Pettan in front of the University of Music and Performing Arts in Vienna, Austria, July 2018.

\section{The networker}

Svanibor was a member of the Executive Board of the ICTM from 2001-2009, Vice President from 2009-2011 and from 2017 till now, and Secretary General from 2011-2017. This means his engagement in the ICTM is longstanding and he has obviously dedicated much of his energy and lifetime to this organisation. His networking qualities are extraordinary and he is truly an international person. I remember many wonderful, enlightening, funny, but also stressful moments during our collaborations within the ICTM. We do share many personal and also professional experiences. As Secretary General of ICTM I was fortunate to inherit the Council in very good shape in terms of operations from Svanibor, also because of his wise choice of the excellent executive assistant with whom I continued to work.

I owe Svanibor so much gratitude for his support on so many levels over these 30 years. He opened many doors for me, in a scholarly and personal sense, and it is a great pleasure and always inspiring to work with him. I will be happy to go on Svanibor, there is still much to do.

\section{References}

Pettan, Svanibor. "Encounter with 'The Others from Within': The Case of Gypsy Musicians in Former Yugoslavia." The World of Music 43, no. 2-3 (2001): 119-137.

Pettan, Svanibor and Titon, Jeff Todd. eds. The Oxford Handbook of Applied Ethnomusicology. Oxford, New York: Oxford University Press, 2015. 